\title{
BPP UTILIZATION BY FARMERS TO SUPPORT INDONESIA AS BARNS THE WORLD
}

\author{
Iranita Haryono*, Astrini Padapi, Ayu Wulandary \\ Department of Agribusiness, Faculty of Science and Technology, University of Muhammadiyah Sidenreng \\ Rappang, Indonesia \\ *corresponding author: iranitaharyono.ih@gmail.com
}

\begin{abstract}
One of the efforts to achieve national food security is by strengthening assistance and counseling to farmers as the main actors. One of the extension links closest to the community and located at the sub-district level is the Peratanian Extension Center (BPP). The function and role of BPP is developed to achieve the desired expectations, namely food self-sufficiency and improvement of farmer welfare. Therefore, there is a need for a special study to be able to determine the level of responsiveness, responsibility and quality of agricultural extension services carried out by the BPP in Sidenreng Rappang Regency. This reserch aims to determine the performance of agricultural extension agents in Sidenreng Rappang Regency in terms of the level of accountability of agricultural extension activities based on indicators of responsiveness, responsibility and quality of extension services. The research was conducted from July to October in Sidenreng Rappang Regency. This research used a survey method. Determination of the sample of this study was carried out purposively on extension workers at the local BPP. Data collected descriptively by cross tabulation. Data analysis used scoring parameters, proportion, maximum, minimum and average values. The results show that the agricultural instructor's Performance Score is 294 which is interpreted into a moderate category score, which means that the ability of the BPP is sufficient to be able to recognize the needs of the assisted farmers, is sufficient to develop extension programs / activities that are in accordance with the wishes / aspirations of local farmers, and sufficient in providing service to farmers.
\end{abstract}

Keywords: Agricultural Instructor Performance, Responsiveness, Responsibility, and Service Quality

http://dx.doi.org/10.21776/ub.agrise.2021.021.2.5

Received 9 October 2020

Accepted 28 April 2021

Available online 30 April 2021

\section{INTRODUCTION}

Food is a basic human need and part of the basic component in realizing quality human resources. One of the efforts to achieve national food security is by strengthening assistance and counseling to farmers as the main actors. The extension system, which previously only consisted of a subsystem of farmers, extension workers, and structural institutions, has become a subsystem of farmers, extension workers, other agribusiness actors, research institutions, education and training institutions.

The extension is carried out with a competitive, democratic, sustainable, and decentralized approach to agribusiness systems and enterprises. One of the extension links closest to the community and located at the sub-district level is the Peratanian Extension Center (BPP). The role and function of BPP are to organize and facilitate extension activities, (Hariadi, 2015), explaining that to increase agricultural production, BPP as a center of extension plays an important role because it becomes the center of activities, both agricultural extension workers, independent and private.

The function and role of BPP are developed to achieve the desired expectations, namely food selfsufficiency and improvement of farmer welfare. The roles and functions of the agricultural extension centers include the preparation of extension programs, providing and disseminating information 
technology, facilitating the development of farmer institutions, facilitating capacity building of extension workers and farmers, carrying out learning processes through piloting and developing farming business models for the main actors and efforts to support food self-sufficiency programs. as well as a meeting place for extension workers and key players and businesses.

Based on the national phenomenon and regional conditions of Sidenreng Rappang Regency in implementing agricultural extension in the framework of empowering farmers, this paper tries to describe the extent to which the BPP of Sidenreng Rappang Regency has performed in carrying out its duties and functions in agricultural extension activities. There needs to be a special study to be able to determine the level of responsiveness, responsibility, and quality of agricultural extension services carried out by the BPP in Sidenreng Rappang Regency.

\section{RESEARCH METHODS}

This study uses a survey method to provide an overview of a particular sample so that a conclusion can be drawn. Determination of the location of this study was carried out purposively in Sidenreng Rappang Regency with the consideration that all BPPs in Sidenreng Rappang Regency have their buildings as many as $11 \mathrm{BPP}$. The research location will be carried out in the district. Sidenreng Rappang. The research time will be carried out from July to October 2020.

The population in this study is the total BPP in Sidrap Regency, amounting to 11 Balai (Dinas Pertanian Kab.Sidrap, 2019), with the target population is Agricultural Extension. Furthermore, the number of samples of respondents was determined using the formula (Djarwanto, 1996) as follows:

$$
\mathrm{n}=\frac{1}{4}\left(\frac{\mathrm{Z}_{\alpha / 2}}{\mathrm{E}}\right)^{2}
$$

\section{Information :}

$\mathrm{n} \quad=$ Number of samples

$\mathrm{Z}=\mathrm{A}$ number that shows the deviation of a variable value from the count in certain standard deviation units

$E=$ Error

From the value (level of significance) to be used in this study, namely: 0.05 , it is expected that the magnitude of the error in the use of the sample (sampling error) is not more than 15 percent. With the formula above, the number of samples can be determined as follows:

$$
\mathrm{n}=\frac{1}{4}\left(\frac{Z_{0,0 / 2}}{0,15}\right)^{2}=\frac{1}{4}\left(\frac{1,96}{0,15}\right)^{2}
$$

$=42.6$ or rounded up to 43 people

So the minimum sample used is 43 people. Of the 43 samples. The sampling technique at the Agricultural Extension Center was carried out by purposive sampling.

Before the data is analyzed further, it will first be tested for validity and reliability. The quality of data resulting from the use of research instruments can be evaluated through validity and reliability tests, each of which is to determine the consistency and accuracy of data collected from the use of the instrument.

The performance indicators of the Agricultural Extension Centers in Sidenreng Rappang district are measured by looking at the level of performance/programs of each actor. The analysis was conducted using a statistical analysis method with scoring rating descriptive. This analysis is used to calculate and describe the level of suitability of interests interpreted by 3 categories of BPP performance applied to the study (Rangkuti, 2003).

\section{RESULTS AND DISCUSSION}

The research was conducted for three months, from July to October 2020 in Sidenreng Rappang Regency. Samples were taken by purposive sampling so that a sample of 43 agricultural extension workers was obtained. The following are the results of the research as a whole.

Table 2. Distribution of the results of respondents' assessment of the performance of the Sidenreng Rappang BPP, an indicator of performance responsiveness

\begin{tabular}{ccc}
\hline Responsiveness & Amount & Persentase (\%) \\
\hline High & 34 & $79 \%$ \\
Moderate & 7 & $16 \%$ \\
Low & 2 & $5 \%$ \\
\hline Total & $\mathbf{4 3}$ & $\mathbf{1 0 0 \%}$ \\
\hline
\end{tabular}


Source: Primary Data, 2020

Based on table 2, it shows that the responsiveness is in the high category, namely 34 (79\%), according to the responsiveness aspect, it is indicated by the ability and experience of the extension agents in identifying the aspirations of farmers' needs and preparing work plans that can answer the problems and needs of farmers who have entered the high category. Identification of needs is carried out by implementing impact points technical, social, and economic. The diversity of farmers' needs requires extension workers to be observant and sensitive to needs which are a priority to be met.

This is by the opinion of Moh. As'ad (1991) states that ability is the potential that a person has to perform a task and is a determinant of performance. High ability will greatly support one's appearance/performance in carrying out routine tasks. The level of ability level will directly affect the level of the target achieved.

Table 3. Distribution of the results of respondents' assessment of the performance of the Sidenreng Rappang BPP district indicator of performance responsibility.

\begin{tabular}{ccc}
\hline Responsibility & Amount & Persentase (\%) \\
\hline High & 15 & $35 \%$ \\
Moderate & 26 & $60 \%$ \\
Low & 2 & $5 \%$ \\
\hline Total & $\mathbf{4 3}$ & $\mathbf{1 0 0 \%}$ \\
\hline
\end{tabular}

Source: Primary Data, 2020

Based on Table 3, the results of the analysis of the performance responsibility of the BPP Sidenreng Rappang Regency in 2020 show an assessment score in the medium category $(60 \%$ or 26 of 43 respondents). the work realization of agricultural extension workers who carry out adequate extension activities by the planning and principles of extension. Efforts to support this require an active role for the community and the role of the district government of Sidenreng Rappang to be able to formulate the right policies according to the needs of farmers, especially those related to technology transfer (transfer of technology) which is currently increasingly sophisticated and sustainable development according to objectives. agricultural extension so that farmers become prosperous. Soenardi (1989) states that the success of extension agents has a positive relationship with the quality of the extension program. On the other hand, Handoko (1987) states that employees must be trained, developed in certain task areas to study new things that will improve their work performance.
Table 4. Distribution of the results of respondents' assessment of the performance of the Sidenreng Rappang BPP performance service quality indicator.

\begin{tabular}{ccc}
\hline $\begin{array}{c}\text { Quality of } \\
\text { Service }\end{array}$ & Amount & Persentase (\%) \\
\hline High & 23 & $53 \%$ \\
Moderate & 19 & $44 \%$ \\
Low & 1 & $2 \%$ \\
\hline Total & $\mathbf{4 3}$ & $\mathbf{1 0 0} \%$ \\
\hline
\end{tabular}

Source: Primary Data, 2020

Based on Table 4, it shows the results of the analysis of the performance appraisal of the BPP Sidenreng Rappang Regency on service quality indicators in 2020, an assessment score is obtained in the high category ( $53 \%$ or 23 of 43 respondents). This means that the quality of extension services to farmers is in the satisfactory category. The implementation of the Exercises and Visits (Laku) has been optimal as the materials and methods used are in the quite appropriate category and the service is very good. In line with the results of this study, $\mathrm{Va}$ den Ban (1999) stated that from counseling to influence human behavior (farmers), several elements were mentioned, namely, the efforts made to influence human behavior by: (1) through education; (2) providing assistance, and (3) implementing policy coercion (law/law). Lesmana (2007) adds that the strategic role and function of agricultural extension institutions, especially in the District and Agricultural Extension is to improve the quality of human resources for farmers in building sustainable agribusiness systems and businesses. Another effort is being made to improve the competence of agricultural extension agents, especially with training and training that are tailored to the conditions of the working area and the development of the world of agriculture so that they can provide technical insights and skills by what farmers need.

Table 5. Frequency distribution of the number of respondents' answers to BPP performance.

\begin{tabular}{ccc}
\hline $\begin{array}{c}\text { Performance } \\
\text { indicators }\end{array}$ & Amount & Persentase (\%) \\
\hline Responsiveness & 98 & $33 \%$ \\
Responsibility & 91 & $31 \%$ \\
Quality of & 105 & $36 \%$ \\
Service & $\mathbf{2 9 4}$ & $\mathbf{1 0 0 \%}$ \\
\hline Total &
\end{tabular}

Source: Primary Data, 2020 
Based on the analysis per performance indicator, the result is that overall (a combination of 3 indicators) using scoring analysis shows that the performance of the BPP Sidenreng Rappang Regency is in the medium category with a total value of 294 , which means that the ability of the BPP is sufficient to be able to recognize the needs of the assisted farmers, it is sufficient to develop extension programs/activities by the wishes/ aspirations of local farmers and sufficient in providing services to farmers. By Dina's opinion (2007) Efforts to improve BPP performance can be done by providing opportunities for extension workers to improve their abilities and capacities through informal and formal education and considering the extension's function as consultants and counterparts by related agencies/agencies in the program preparation, so that extension workers feel he is demanded to be a specialist who can analyze the real needs of farmers and provide excellent service to users. BPP Sidenreng Rappang Regency is expected to be able to evaluate itself and pay more attention and improve its ability and performance so that farmers in their respective working areas (WKBPP) can further increase the level of adoption of their innovations and make the lives of farmers in their target areas more prosperous so that their existence (existence) is close to the community. can be optimized according to their roles and functions.

In line with dina lesmana ( 2007 ) primary mission national economic development by empowering the community and the economic strength, national especially small businesses, middle class and cooperatives in the face the challenge of globalization and the role and function is very strategic, bpp given that agriculture in indonesia is dominated by small scale enterprises run by the berjuta-juta, farmers then institutional strengthening and improving the performance of extension that directly exposed to the farmers is very important fitrin yuanita ( 2018 ) efforts to achieve food security salahsatunya national traveled to strengthen the agricultural counseling ( $b p p$ ).Bpp as an knot coordinate the agricultural development in the sub district .The role and function of bpp is organizing and menfasilitasi extension activities .The study is known that the programa agricultural counseling district, availability of information in bpp, the development of farmers in the institutional bpp, bpp to function menfasilitasi pilot, bpp function as a meeting place, and the role and function of bpp overall in magelang with in good category

\section{CONCLUSION}

Based on the results of the analysis and discussion presented in the previous section, it can be concluded that the performance of the BPP of
Sidenreng Rappang Regency is in the medium category with a total value of 294 . Thus it needs joint efforts and hard work from various parties (agencies, entrepreneurs/private sector, farmers) to work together. in improving the performance of the BPP Sidenreng Rappsang Regency in the future, especially in carrying out its duties and functions in the community.

\section{ACKNOWLEDGEMENTS}

My thanks go to all those who helped in completing this article and to the Ministry of Research, Technology and Higher Education as a provider of research grants.

\section{REFERENCES}

Danield C. Feldman. 1986. Individual in Organizations. New York: McGraw Hill, Series in Management. 32-52.

Departemen Pertanian. (2008). Peraturan Menteri Pertanian Nomor: 61/permentan/ot.140/11/2008 Tentang Pedoman Pembinaan Penyuluh Pertanian Swadaya dan Penyuluh Swasta.

Handoko, T. Hani. 1987. Manajemen Personalia dan Sumberdaya Manusia. BPFE UGM Press, Yogyakarta

Moh. As’ad. 1991. Pisikogi Industri . Ed.Library. Yogyakarta. P. 47-48

Lesmana, D. 2007. Kinerja Balai Penyuluhan Pertanian Kota Samarinda. Samarinda:https://agribisnisfpumjurnal.files. wordpress.com/2012/03/jurnalvol- 4-no-2dina.pdf

Lukman Fuad. 2010. Analisis Kinerja Penyuluh Berdasarkan Persepsi Kelompok Tani Ternak Di Kecamatan Tompobulu Kabupaten Maros.Universitas Hasanuddinn. Makassardst.

Soenardi. 1989. Beberapa Faktor Lingkungan Kerja Yang Mempengaruhi Keberhasilan PPL Melaksanakan Tugasnya (Tesis), Yogyakarta: Program Pascasarjana, UGM

Sulistiyani Ambar T. dn Rosidah. 2003. Manajemen Sumber Daya Manusia. Cetakan Pertama. Penerbit Graha Ilmu. Yogyakarta

Thoriq M. As-Suwaidan dan Faishal Umar Basyarohil. 2005. Pemimpin Masa Depan, Jakarta: Gema Insani. 
Van den Ban AW, Hawkins HS. 1999. Penyuluhan Pertanian. Yogyakarta: Penerbit KanisiuWard J, Peppard J, 2009. Strategic Planning for Information System. England: John Wiley \& Sons, Ltd. 
This page is intentionally left blank 